\title{
Comparison of the effectiveness of two treatment modalities for chronic anal fissure: Botox versus sphincterotomy
}

\author{
Coşkun Çakır ${ }^{1}$ (D), Ufuk Oğuz İdiz (D), ỉbrahim Aydın² (D), Deniz Fırat ${ }^{3}$ (D), Abdulhakim İbrahim Ulusoy ${ }^{4}$ (D), Pınar Yazıcı ${ }^{5}$ (D) \\ ${ }^{1}$ Clinic of General Surgery, Istanbul Training and Research Hospital, Istanbul, Turkey \\ ${ }^{2}$ Clinic of General Surgery, Avicenna Hospital, Istanbul, Turkey \\ ${ }^{3}$ Clinic of General Surgery, Bursa Yuksek Ihtisas Training and Research Hospital, Bursa, Turkey \\ ${ }^{4}$ Clinic of General Surgery, Okmeydani Training and Research Hospital, Istanbul, Turkey \\ ${ }^{5}$ Clinic of General Surgery, Sisli Hamidiye Etfal Training and Research Hospital, Istanbul, Turkey
}

\begin{abstract}
Objective: Anal fissure is a common health problem that affects the quality of life of young patients. The aim of our study was to benchmark results of lateral internal sphincterotomy (LIS) and botulinum toxin injection in the treatment of chronic anal fissure.

Material and Methods: This multi-center, retrospective study used data from 135 chronic anal fissure patients. Patients' demographic features, clinical findings, fissure characteristics, post-defecation pain score, rectal bleeding or pruritus, and treatment satisfaction scores were recorded. Patients' data were collected from the hospital records and patients with all of this data available were called and invited to the hospital for examination.

Results: Seventy-four LIS and 61 botulinum toxin applied patients were included. Symptom duration, hospitalization period, and duration of remission of complaints after the treatment were significantly higher in the LIS group $(p<0.001)$. However, pruritus in anus and relapses were found to be higher in the botulinum toxin group ( $p=0.04$ and $p=0.043$, respectively). Abscess and fistula were observed in one patient's perianal region in the LIS group, and an abscess was observed in one patient in the botulinum toxin group. There was no significant difference in treatment satisfaction rates and postoperative complications.
\end{abstract}

Conclusion: Botulinum toxin yields satisfying results that are comparable to LIS. Patient selection may help mitigate this disease and allow it to be considered a good alternative option to surgery.

Keywords: Chronic anal fissure, botulinum toxin, lateral internal sphincterotomy, incontinence

Cite this article as: Çakır C, İiz UO, Aydın I, Fırat D, Ulusuyor Al, Yazıcı P. Comparison of the effectiveness of two treatment modalities for chronic anal fissure: Botox versus sphincterotomy. Turk J Surg 2020; 36 (3): 264-270.

\section{Corresponding Author}

Ufuk Oğuz İdiz

E-mail: oguzidiz@yahoo.com

Received: 26.04 .2019

Accepted: 30.01 .2020

Available Online Date: 28.09.2020

(o Copyright 2020 by Turkish Surgical Society Available online at www.turkjsurg.com

DOI: $10.47717 /$ turkjsurg.2020.4492

\section{INTRODUCTION}

Anal fissure is a common and major problem that affects the quality of life of the patients. Generally, pain and bleeding, both during and after defecation, are among the most frequent symptoms.

In etiopathogenesis, there are usually sphincter spasms and mucosal ischemia based on the mucosal defect that occur following local trauma of the squamous lining in the anal channel $(1,2)$. Although they are usually located in the posterior midline, their atypical localization should bring to mind inflammatory bowel disease, tuberculosis, trauma, and other malignancies (3).

In the treatment of chronic anal fissure, many medical and surgical treatment modalities have been identified. Although surgical treatment modalities are the golden standard, botulinum toxin injection is considered an effective treatment modality $(4,5)$. Among the surgical treatment modalities, Lateral Internal Sphincterotomy (LIS) has a success rate of up to $96 \%$ and a recurrence rate of $2.3-3 \%$ in the treatment of chronic fissures $(6,7)$. In spite of these high success rates, it has complications such as bleeding, pain, and incontinence (5). After LIS, fecal and/ or intestinal gas incontinence rates as high as 10\%-30\% have been reported $(8,9)$.

Thus, alternative treatment methods to surgical treatment are being developed to protect patients from the adverse effects of LIS. For example, topical nitroglycerin ointment, injection of botulinum toxin and oral or topical calcium chan- 
nel blockers reduce the sphincter pressure temporarily and reversibly until the fissure recovers $(10,11)$. Botulinum $A$ toxin has been used since the late 20th century in the treatment of anal fissure. It shows its effect by blocking acetylcholine neuromuscular transmitter activity, ensuring that a temporary chemical sphincterotomy is obtained $(12,13)$.

In the literature, there are studies comparing LIS and botulinum toxin injection, but these studies' limited numbers of patients draw attention (5). In this study, regarding the treatment of chronic anal fissure, patients to whom LIS and botulinum toxin injection had been applied were compared, and their satisfaction states were evaluated.

\section{MATERIAL and METHODS}

This retrospectively designed study received approval from the Local Human Ethics Committee (March 2016 with the no: 631). One hundred thirty-five patients to whom lateral internal sphincterotomy or botulinum toxin injection was applied to treat chronic anal fissure at five different hospitals between 01.01.2014 and 01.06.2015 were included in this study after obtaining informed consents of patients. The inclusion criteria for the study were as follows: being between the ages of 18 to 80 , having received LIS or BTI to treat chronic anal fissure, and having at least 12 months of follow-up. The exclusion criteria for the study were as follows: having a complicated anal fissure (stenosis, abscess, fistula or hemorrhoid) having an acute anal fissure, having been treated by another treatment modality except for LIS or BTI, having immune deficiency, being infected sexually, having an inflammatory bowel disease, having tuberculosis, having a diagnosis of leukemia, having large bowel malignancy, or being pregnant. The progression of complications in the postoperative period included postspinal headache, perianal abscess and fistula, and temporary or permanent intestinal gas or fecal incontinence. Recurrence was evaluated as a separate criterion. LIS treatment was applied if recurrence was observed in BTI-applied patients.

According to the treatment modality, the patients were separated into two groups: the LIS group and the BTI group.

\section{LIS}

The LIS procedure was carried out in a jackknife position for patients in whom spinal anesthesia was not contraindicated and in the lithotomy position for patients in whom spinal anesthesia was contraindicated (those with improper posture or cardiac problems). Lateral internal sphincterotomy was performed with a $10 \mathrm{~mm}$ incision at the level of the dentate line and at the 3 o'clock level of the anal channel.

\section{Botox Injection}

The BTI procedure was carried out by a 25 IU botulinum toxin injection to the internal anal sphincter at 3 o'clock and 9 o'clock levels (50 IU in total) while the patients were in a semi-jackknife position.

All patients were discharged with a medication regimen of 500 mg cefuroxime axetil (Enfexia, Bilim Ilac, Istanbul, Turkey) twice daily for 10 days. Additionally, postoperative stool softener and Sitz baths were advised for all patients for three weeks to avoid constipation and reduce infection, pain, and bleeding.

Patient age, sex, locations of the anal fissures, pre-treatment durations of the patients' complaints, whether any treatment had previously been applied due to anal fissure, treatment modality applied (LIS or BTI), treatment dates, hospitalization periods, and the days of the treatment on which the complaint was completely terminated, were determined from the patients' hospitalization and outpatient clinic application files. Patients with all of this information available were called and invited to the hospital for control purposes. Their current symptoms were noted, and an anorectal examination was administered. Their current post-defecation pain was scored according to a visual analogue scale (VAS) ranging from 0 to 10 (0: no pain, 10: unable to bear pain), on whether they had bleeding, whether they had pruritus in anus, and the FivePoint Horizontal Scale (FPHS) to assess their satisfaction level for the applied treatment (Table 1).

\section{Statistical Analysis}

SPSS 15.0 (Armonk, NY, USA) for Windows program was used for statistical analysis. Descriptive statistics were given as number and percentage for categorical variables and as average, standard deviation, and median for numeric variables. For comparisons between two independent groups, the Mann-Whitney $U$ test was applied since numeric variables did not provide a normal distribution. Categorical values were tested via the Chi-Square test and Fisher exact test in the groups. Statistical significance level was set as $p<0.05$.

\section{RESULTS}

Seventy-four LIS (mean age 37.1 years, F/M: 67/6) and 61 BTI (mean age: 39.5 years, F/M: 29/32) patients were included into the study (Figure 1). In both groups, there was no statistically

Table 1. Five-point horizontal scale (FPHS)

\begin{tabular}{|l|l|}
\hline Points & Definition \\
\hline 1 & Very Unsatisfied \\
\hline 2 & Somewhat Unsatisfied \\
\hline 3 & Neither Satisfied nor Unsatisfied \\
\hline 4 & Somewhat Satisfied \\
\hline 5 & Very Satisfied \\
\hline
\end{tabular}




\section{Anal fissure patients}

(n: 217)

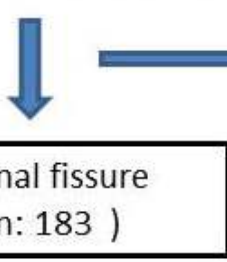

Chronic anal fissure
patients $(n: 183$

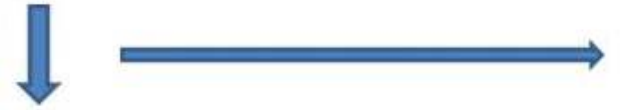

Patients who met the

criteria (n: 155 )

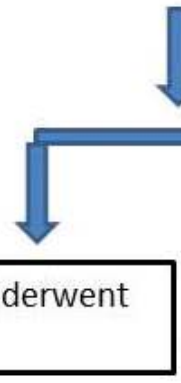

Patients who underwent BTI (n: 61)
Acute anal fissures

excluded ( $n: 34$ )
Patients who did not fulfil the criteria were excluded ( $\mathrm{n}$ : 28)

\section{Patients were excluded because of data entry errors and missing hospital visit ( $n: 20)$}

significant difference in age $(p=0.356)$. However, the male ratio of the patients to whom Botulinum Toxin Injection was applied was found to be statistically significantly higher than the patients to whom LIS was applied $(p<0.001)$.

Symptom duration, hospitalization period, and duration of remission of the complaints after treatment of the LIS group were statistically and significantly higher than those of the BTI group $(p<0.001)$. Abscess and fistula development in 1 patient's perianal region were observed, as was postspinal headache in 2 patients to whom LIS was applied, and an abscess was observed in 1 patient from the BTI group.

No statistically significant differences were determined between the groups at VAS pain score or FPHS treatment satisfaction rates during defecation $(p=0.579$ and $p=0.861$, respectively) (Table 2).

When symptom and complication rates were examined in control visits, pruritus in anus was found to be statistically higher among BTI-applied patients ( $p=0.04)$.

In the long-term follow-ups in the LIS group, permanent intestinal gas and fecal incontinence in 1 patient, temporary intes- tinal gas and fecal incontinence in 1 patient (recovered at the fifth month), and temporary intestinal gas incontinence in 1 patient were observed. In the BTI group, temporary intestinal gas incontinence was observed in only 1 patient. When total complications were observed, no statistically significant difference was found between the groups ( $p=0.290)$ (Table 2). When recurrence rates of the groups were evaluated, the number of recurrences was statistically higher in the BTI-applied patients than the LIS-applied patients ( $p=0.043)$.

BTI patients were separated into two groups according to recurrence. There were no statistically significant differences between the groups in age and $\operatorname{sex}(p=0.957$ and $p=0.450$, respectively). However, the patients who had a longer pre-treatment symptom duration had a significantly higher recurrence rate, and it was observed that all of the patients with a growing relapse had fissure with posterior localization $(p<0.001$ and $p$ : 0.016 , respectively). Additionally, in patients with a growing relapse, the VAS score was higher, the FPHS rates were lower, and the patients had more rectal bleeding and pruritus among their anus complaints $(p=0.001)$ (Table 3$)$. 
Table 2. Comparison of Lateral internal sphincterotomy (LIS) and Botulinum toxin injection (BTI)

\begin{tabular}{|c|c|c|c|}
\hline & BTI (n: 61) & LIS (n: 74) & $\mathbf{P}$ \\
\hline Age (years), (mean $\pm S D$ ) & $39.5 \pm 11.9$ & $37.1 \pm 11.4$ & 0.356 \\
\hline $\begin{array}{l}\text { Sex } \\
\quad \text { Female, n (\%) } \\
\text { Male, n (\%) }\end{array}$ & $\begin{array}{l}29(47.5) \\
32(52.5)\end{array}$ & $\begin{array}{c}67(91.8) \\
6(8.2)\end{array}$ & $<0.001$ \\
\hline $\begin{array}{l}\text { Location of fissure } \\
\text { Anterior, n (\%) } \\
\text { Posterior, n (\%) }\end{array}$ & $\begin{array}{l}26(42.6) \\
35(57.4)\end{array}$ & $\begin{array}{l}28(38.4) \\
45(61.6)\end{array}$ & 0.616 \\
\hline Duration of symptoms (months) (mean $\pm \mathrm{SD}$ ) & $21.6 \pm 12.5$ & $13.0 \pm 4.0$ & $<0.001$ \\
\hline $\begin{array}{l}\text { Anesthesia (\%) } \\
\text { Spinal } \\
\text { General } \\
\text { Local }\end{array}$ & $\begin{array}{c}6(9.8) \\
0(0.0) \\
55(90.2)\end{array}$ & $\begin{array}{c}63(86.3) \\
8(11.0) \\
2(2.7)\end{array}$ & $<0.001$ \\
\hline Length of hospital stay, (hours) (mean \pm SD) & $2.8 \pm 3.8$ & $24.8 \pm 5.0$ & $<0.001$ \\
\hline Recovery time of complaints (days) (mean \pm SD) & $1.9 \pm 0.6$ & $7.2 \pm 3.1$ & $<0.001$ \\
\hline Pain score during defecation $(V A S)^{*}($ mean $\pm S D)$ & $0.46 \pm 0.81$ & $0.37 \pm 0.71$ & 0.579 \\
\hline Patient satisfaction $(\mathrm{FPHS})^{* *}($ mean $\pm \mathrm{SD})$ & $4.4 \pm 1.0$ & $4.5 \pm 0.9$ & 0.861 \\
\hline Rectal bleeding during follow-up period n (\%) & $7(11.5)$ & $2(2.7)$ & 0.079 \\
\hline Pruritus ani during follow-up period n (\%) & $10(16.4)$ & $4(5.5)$ & 0.040 \\
\hline Temporary flatus incontinence $\mathrm{n}(\%)$ & $1(1.6)$ & $2(2.7)$ & 0.625 \\
\hline Temporary fecal incontinence $\mathrm{n}(\%)$ & $0(0.0)$ & $1(1.4)$ & 1.000 \\
\hline Persistent flatus incontinence $\mathrm{n}(\%)$ & $0(0.0)$ & $1(1.4)$ & 1.000 \\
\hline Persistent fecal incontinence $\mathrm{n}(\%)$ & $0(0.0)$ & $1(1.4)$ & 1.000 \\
\hline Postoperative perianal infection n (\%) & $1(1.6)$ & $1(1.4)$ & 1.000 \\
\hline Postoperative complication n (\%) & $2(3.3)$ & $6(8.2)$ & 0.290 \\
\hline Recurrence rate $\mathrm{n}(\%)$ & $8(13.1)$ & $2(2.7)$ & 0.043 \\
\hline
\end{tabular}

\section{DISCUSSION}

The most frequently applied treatment modality for chronic anal fissure is LIS, which is acknowledged as the golden standard (14). Complications such as fecal incontinence, abscess, and intestinal gas incontinence observed after LIS have provided a basis for applying less invasive treatment modalities. Topical nitroglycerin ointment, injection of botulinum toxin and oral or topical calcium channel blockers are some non-surgical treatment modalities $(10,11)$.

There are many studies comparing defined treatment modalities for anal fissure. In a randomized study in which LIS and topical nitroglycerin ointment were compared in 54 patients, at the end of a 10-week treatment and follow-up period, a 100\% recovery in LIS patients and an 89\% recovery in topical nitroglycerin ointment patients was observed. However, when the complications were evaluated, the incidence rate of minor fecal incontinence drew attention as being 44\% in patients to whom LIS was applied and $0 \%$ in patients to whom topical nitroglycer- in ointment was applied. After a 2-year follow-up, residual fecal incontinence was observed in 15\% of the LIS-applied patients (15). Also, in the literature, the rate of incidence of fecal incontinence is between $3 \%$ and $16 \%$ after LIS treatment (4).

In studies carried out on botulinum toxin injection, which is a less invasive treatment modality than LIS but has a higher rate of recurrence compared to surgical treatment options, there is a decrease in complication rates, especially in that of incontinence (16). In a randomized study, botulinum toxin (n: 15) and saline (n: 15) injection to the internal anal sphincter were compared in 30 patients with chronic anal fissure. In the $2^{\text {nd }}$ month, compared with the controls after treatment, a statistically significant recovery was observed in the botulinum toxin-applied group. In this patient group, re-injection was required for some patients, and no relapse was observed in any of them over an approximately 16-month follow-up (17). In a randomized study in which botulinum toxin injection and LIS were compared, Botox was applied to 61 patients and LIS was applied to 50 pa- 
Table 3. Demographics and clinical features of the patients who underwent Botulinum toxin injection in terms of recurrence

\begin{tabular}{|c|c|c|c|}
\hline & \multicolumn{3}{|c|}{ Recurrence } \\
\hline & No & Yes & p \\
\hline Age (years), (mean $\pm \mathrm{SD})$ & $39.3 \pm 11.4$ & $40.6 \pm 15.8$ & 0.957 \\
\hline $\begin{array}{l}\text { Sex } \\
\quad \text { Female, n (\%) } \\
\text { Male, n (\%) }\end{array}$ & $\begin{array}{l}24(45.3) \\
29(54.7)\end{array}$ & $\begin{array}{l}5(62.5) \\
3(37.5) \\
\end{array}$ & 0.460 \\
\hline $\begin{array}{c}\text { Location of fissure } \\
\text { Anterior, n (\%) } \\
\text { Posterior, n (\%) }\end{array}$ & $\begin{array}{l}26(49.1) \\
27(50.9)\end{array}$ & $\begin{array}{l}0(0.0) \\
8(100)\end{array}$ & 0.016 \\
\hline Duration of symptoms (months) (mean \pm SD) & & $18.5 \pm 4.5$ & $<0.001$ \\
\hline Recovery time after treatment (day) (mean \pm SD) & $1.8 \pm 0.6$ & $2.1 \pm 0.4$ & 0.133 \\
\hline Pain score during defecation* (VAS) (mean \pm SD) & $0.21 \pm 0.45$ & $2.13 \pm 0.64$ & $<0.001$ \\
\hline Patient satisfaction score $(F P H S){ }^{* *}($ mean \pm SD $)$ & $4.8 \pm 0.5$ & $2.3 \pm 0.7$ & $<0.001$ \\
\hline Rectal bleeding during follow-up period n (\%) & $0(0.0)$ & $7(87.5)$ & $<0.001$ \\
\hline Pruritus ani during follow-up period n (\%) & $2(3.8)$ & $8(100)$ & $<0.001$ \\
\hline Temporary flatus incontinence n (\%) & $1(1.9)$ & $0(0.0)$ & 1.000 \\
\hline Postoperative perianal infection n (\%) & $1(1.9)$ & $0(0.0)$ & 1.000 \\
\hline Total complication rate $\mathrm{n}(\%)$ & $2(3.8)$ & $0(0.0)$ & 1.000 \\
\hline
\end{tabular}

tients. In the Botox-applied group, recovery rates of $73.8 \%$ were obtained in the $2^{\text {nd }}$ month, and after the second injection, this rate reached $86.9 \%$. A success rate of $94 \%$ was achieved in the LIS-applied patients, but the success rate in the Botox group remained at $75 \%$. When the complication rates were observed, temporary anal incontinence was determined to be present in $16 \%$ of the LIS-applied patients, whereas no anal incontinence was reported for the Botox-applied patients. Additionally, for the patients, the duration until starting to perform daily activities was significantly lower in Botox-applied patients than in the LIS-applied ones (18). In another study evaluating 100 patients who received Botox treatment due to chronic anal fissure, after the 6-month follow-ups, total recovery was observed in $79 \%$ of the patients, and recurrence was observed in $8 \%$. Additionally, temporary fecal incontinence was observed in $7 \%$ of the patients (19).

In our study, total complication rates were higher in the LIS group, but there were no significant differences. Additionally, temporary intestinal gas or fecal incontinence rates were higher in the LIS group, but there were no significant differences. Permanent incontinence was observed in only 1 patient who received LIS treatment. There was no serious incontinence problem in the BTI group, except for only 1 of the patients who had temporary intestinal gas incontinence. In the BTI group of our study, after a 12-month follow-up, complete recovery rate was $86.9 \%$, whereas recurrence was determined in only 8 patients. In studies that include longer follow-up periods, recurrence rates have been determined to be significantly higher (41\%) (20), but in our study, the follow-up period was approximately 14.2 months, and long-term follow-ups will be evaluated again. In the literature, etiological factors for high recurrence rates have been reported as follows: the time interval between symptom onset and surgery, the need for re-injection or high-dose botulinum toxin, and a minimum decrease in anal sphincter pressure after treatment (20). In our study, the recurrences observed in the Botox-applied patients were specifically related, with fissure being with posterior localization and a longer interval between symptom onset and surgery.

In conclusion, among many treatment modalities that have been defined for anal fissure treatment, LIS, which is acknowledged as the gold standard, is both more invasive and has higher complication rates than other modalities. Botulinum Toxin Injection, which is one of the less invasive modalities, has higher recurrent rates but can be accepted as an alternative treatment modality for select patients due to its low complication rates. Observing recurrence more frequently in patients with a longterm disease and in patients with posterior localization shows that patient selection is an important issue. BTI may be applied as a first-step treatment modality to patients who have a low risk of recurrence.

\section{ACKNOWLEDGMENTS}

This research received no specific grant from any funding agency in the public, commercial, or not-for-profit sectors. 
Ethics Committee Approval: Ethics committee approval was received for this study from Local Human Ethics Committee 2016/631.

Peer-review: Externally peer-reviewed.

Author Contributions: Concept - C.Ç., U.O.I.; Design - I.A., D.F., P.Y.; Supervision - C.Ç., U.O.I., A.I.U.; Resource - C.Ç., P.Y.; Materials - I.A., D.F., A.I.U.; Data Collection and/or Processing - U.O.I., D.F., P.Y.; Analysis and Interpretation P.Y., C.Ç., I.A.; Literature Review - U.O.I., D.F., I.A.; Writing Manuscript - C.Ç., I.A., A.I.U.; Critical Reviews - U.O.I., P.Y.

Conflict of Interest: The authors have no conflicts of interest to declare.

Financial Disclosure: The authors declared that this study has received no financial support.

\section{REFERENCES}

1. Nelson RL, Abcarian H, Davis FG, Persky V. Prevalence of benign anorectal disease in a randomly selected population. Dis Colon Rectum. 1995; 38: 341-4. [CrossRef]

2. Schouten WR, Briel JW, Auwerda JJ. Relationship between anal pressure and anodermal blood flow. The vascular pathogenesis of anal fissures. Dis Colon Rectum 1994; 37: 664-9. [CrossRef]

3. Piccinni G, Poli E, Angrisano A, Sciusco A, Testini M. Botox for chronic anal fissure: is it useful? a clinical experience with mid-term follow-up. Acta Biomed 2009; 80: 238-42. [CrossRef]

4. Sinha R, Kaiser AM. Efficacy of management algorithm for reducing need for sphincterotomy in chronic anal fissures. Colorectal Dis 2012; 14: 760-4. [CrossRef]

5. Chen H-L, Woo X-B, Wang H-S, Lin Y-J, Lou H-X, Chen Y-H, et al. Botulinum toxin injection versus lateral internal sphincterotomy for chronic anal fissure: a meta-analysis of randomized control trials. Tech Coloproctol 2014; 18: 693-8. [CrossRef]

6. Hyman N. Incontinence after lateral internal sphincterotomy: a prospective study and quality of life assessment. Dis Colon Rectum 2004; 47: 35-8. [CrossRef]

7. Hasse C, Brune M, Bachmann S, Lorenz W, Rothmund M, Sitter H. Lateral, partial sphincter myotomy as therapy of chronic anal fissue. Longterm outcome of an epidemiological cohort study. Chirurg 2004; 75: 160-7. [CrossRef]
8. Nelson R. Operative procedures for fissure in ano. Cochrane database Syst Rev 2002; 1: CD002199. [CrossRef]

9. Casillas S, Hull TL, Zutshi M, Trzcinski R, Bast JF, Xu M. Incontinence after a lateral internal sphincterotomy: are we underestimating it? Dis Colon Rectum 2005; 48: 1193-9. [CrossRef]

10. Asim M, Lowrie N, Stewart J, Lolohea S, Van Dalen R. Botulinum toxin versus botulinum toxin with low-dose glyceryltrinitrate for healing of chronic anal fissure: a prospective, randomised trial. N Z Med J 2014; 127: 80-6. [CrossRef]

11. Farouk R. Sphincter-preserving therapy for treating a chronic anal fissure: long-term outcomes. Ann Coloproctol 2014; 30: 132-4. [CrossRef]

12. Jost WH, Schimrigk K. Use of botulinum toxin in anal fissure. Dis Colon Rectum 1993; 36: 974. [CrossRef]

13. Oh C, Divino CM, Steinhagen RM. Anal fissure. 20-year experience. Dis Colon Rectum 1995; 38: 378-82. [CrossRef]

14. Ram E, Alper D, Stein GY, Bramnik Z, Dreznik Z. Internal anal sphincter function following lateral internal sphincterotomy for anal fissure: a long-term manometric study. Ann Surg 2005; 242: 208-11. [CrossRef]

15. Oettlé GJ. Glyceryl trinitrate vs. sphincterotomy for treatment of chronic fissure-in-ano: a randomized, controlled trial. Dis Colon Rectum 1997; 40: 1318-20. [CrossRef]

16. Shao W-J, Li G-C, Zhang Z-K. Systematic review and meta-analysis of randomized controlled trials comparing botulinum toxin injection with lateral internal sphincterotomy for chronic anal fissure. Int $\mathrm{I}$ Colorectal Dis 2009; 24: 995-1000. [CrossRef]

17. Maria G, Cassetta E, Gui D, Brisinda G, Bentivoglio AR, Albanese A. A comparison of botulinum toxin and saline for the treatment of chronic anal fissure. N Engl J Med 1998; 338: 217-20. [CrossRef]

18. Mentes BB, Irkorucu O, Akin M, Leventoglu S, Tatlicioglu E. Comparison of botulinum toxin injection and lateral internal sphincterotomy for the treatment of chronic anal fissure. Dis Colon Rectum 2003; 46: 232-7. [CrossRef]

19. Jost WH. One hundred cases of anal fissure treated with botulin toxin: early and long-term results. Dis Colon Rectum 1997; 40: 1029-32. [CrossRef]

20. Jost WH, Schrank B. Repeat botulin toxin injections in anal fissure: in patients with relapse and after insufficient effect of first treatment. Dig Dis Sci 1999; 44: 1588-9. [CrossRef] 


\section{ORIJINAL ÇALIŞMA-ÖZET}

Turk J Surg 2020; 36 (3): 264-270

\section{Kronik anal fissür tedavisinde iki modalitenin karşılaştırılması: Botoks ve sfinkterotomi}

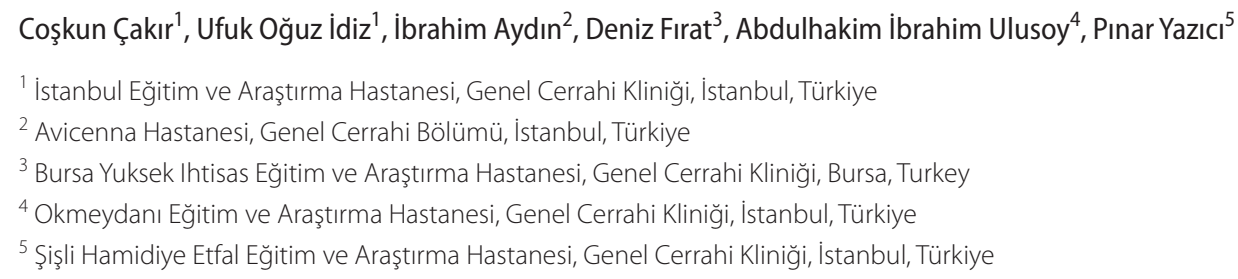

\section{ÖZET}

Giriş ve Amaç: Anal fissür, genç hastaların yaşam kalitesini etkileyen yaygın bir sağlık problemidir. Çalışmamızın amacı, kronik anal fissür tedavisinde lateral internal sfinkterotomi (LiS) ve botulinum toksin enjeksiyonu sonuçlarını karşılaştırmaktır.

Gereç ve Yöntem: Bu çok merkezli, retrospektif çalışma 135 kronik anal fissür hastasının verilerinin kullanılması ile hazırlanmışıı. Hastaların demografik özellikleri, klinik bulguları, fissür özellikleri, dışkılama sonrası ağıı skoru, rektal kanama veya pruritus ve tedavi memnuniyet skorları not edildi. Hasta bilgileri hastane bilgisayar sistemlerinin taranması ile toplandı ve araştıılan kayıtları taşıyan hastalar telefon ile aranılarak muayene için hastaneye davet edildi.

Bulgular: Yetmiş dört Lis ve 61 Botulinum Toksini uygulanmış hasta çalışmaya dahil edilmiştir. Semptomların süresi, hastanede kalış süresi ve tedavi sonrası remisyon süresi LiS grubunda anlamlı olarak yüksek bulundu $(p<0.001)$. Ancak, anal kaşıntı ve rekürrens botulinum toksin grubunda daha yüksek olduğu bulundu (sırasıyla, $p=0.04$ ve $p=0.043$ ). Bir hastanın perianal bölgesinde Lís uygulanan gruptaki bir hastada perianal apse ve fistül, botulinum toksin enjeksiyonu uygulanan grupta bir hastada perianal apse gözlendi. Tedavi memnuniyet oranları ve postoperatif komplikasyonlar arasında anlamlı bir fark yoktu.

Sonuç: Botulinum Toxininin, LiS ile karşılaştırıldığında tatmin edici sonuçlara sahip olduğu görülmektedir. Hasta seçimi botulinum toksininin tedavisinde cerrahiye iyi bir alternatif olarak görülmesine yardımcı olacaktır.

Anahtar Kelimeler: Kronik anal fissür, botilinum toksin, lateral internal sfinkterotomi, inkontinans

Doi: $10.47717 /$ turkjsurg.2020.4492 